\title{
Long-term Response of 'Hamlin' Orange Trees to Controlled-release Nitrogen Fertilizers
}

\author{
Thomas A. Obreza ${ }^{1}$ \\ Soil and Water Science Department, University of Florida, P.O. Box 110290 , \\ Gainesville, FL 32611
}

\section{Robert E. Rouse \\ Horticultural Sciences Department, UniversityofFlorida, Southwest Florida Research and Education Center, 2686 State Road 29 North, Immokalee, FL 34142 \\ Additional index words. Citrus sinensis, fruit yield, total soluble solids, juice quality, isobutylidene diurea, methylene urea}

\begin{abstract}
Controlled-release $\mathrm{N}(\mathrm{CRN})$ fertilizer is receiving interest as a possible nutrient best management practice (BMP) for Florida citrus production, but grower acceptance will be limited until cost decreases and familiarity with CRN materials increases. The objective of this study was to compare long-term citrus production resulting from $\mathbf{N}$ fertilizer programs containing isobutylidene diurea (IBDU) or methylene urea (MU) with a conventional water-soluble $\mathbf{N}$ fertilizer program to determine the magnitude of horticultural utility provided by CRN. We applied $N$ to a newly planted 'Hamlin' orange (Citrus sinensis L. Osbeck) orchard using three sources $(100 \%$ ammonium nitrate $(\mathrm{AN})$; a 50/50 mixture of $A N / I B D U ;$ a $60 / 40$ mixture of $A N / M U)$ at four rates $(0.25,0.5,1.0$, and 2.0 or 1.5 times the recommended annual rate) in factorial combination, and continued for 7 years. During this period, AN was applied 31 times vs. about 15 times for CRN-containing fertilizers. We measured fruit yield, juice quality, and total soluble solids (TSS) yield in years 4 through 7 and found that they generally were not affected by $\mathbf{N}$ source, especially when year-to-year variation was taken into account. In year 7, fruit and TSS yields of well-fertilized trees reached 153 and $9.2 \mathrm{~kg} /$ tree, respectively. Maximum 4-year cumulative fruit and TSS yields (486 and $27.6 \mathrm{~kg} /$ tree, respectively) occurred at an $\mathrm{N}$ rate of $200 \mathrm{~kg} / \mathrm{ha}$. Maximum juice quality occurred at $180 \mathrm{~kg} \mathrm{~N} / \mathrm{ha}$. We feel the CRN materials tested could be used successfully in a nutritional BMP program that would maintain high yields while potentially decreasing $\mathrm{N}$ loss to the environment.
\end{abstract}

Controlled-release nitrogen $(\mathrm{CRN})$ is defined as a fertilizer that releases its $\mathrm{N}$ to the soil in a manner that matches the need of a growing plant. The concept of integrating CRN into Florida citrus nutrient management programs originated about 25 years ago, but it has not been widely accepted by the citrus industry because of higher material cost compared with water-soluble $\mathrm{N}$, and because producers are hesitant to change from $\mathrm{N}$ sources they know are effective to materials with unfamiliar characteristics. However, state agencies responsible for water resource protection (Florida Dept. of Environmental Protection and Florida Dept. of Agriculture and Consumer Services) have renewed interest in promoting the use of CRN to produce citrus, especially in areas like the central Florida ridge where groundwater contamination is a concern. Cost-sharing provided by these agencies as part of a voluntary nutrient BMP program may allow affordable use of CRN, but producers still need to be convinced of its efficacy before commercial use significantly expands.

Received for publication 2 Oct. 2005. Accepted for publication 29 Nov. 2005. We thank A. Duda $\&$ Sons, Inc. for providing the citrus orchard used in this work.

${ }^{1}$ To whom reprint requests should be addressed; e-mail taob@ifas.ufl.edu.
Florida citrus trees have not shown a preference for any particular N source (Leonard, et al., 1961; Smith et al., 1968), so the industry has used soluble $\mathrm{N}$ like ammonium nitrate as fertilizer for decades. In the 1980s, speculation that nitrate $\mathrm{N}$ was leaching to groundwater beneath commercial orchards prompted initial studies on horticultural effects of CRN applied to bearing trees. At the time, the environmental advantage ofCRN was assumed, but it was later confirmed by leaching studies (Paramasivam et al., 2001; Wang and Alva, 1996). Koo (1986) found that TSS yields of mature 'Valencia' and 'Pineapple' orange trees were greater with IBDU compared with sulfur-coated urea (SCU) or AN in 2 of 4 years, and that highest yields were obtained at $200 \mathrm{~kg} \mathrm{~N} / \mathrm{ha} /$ year. CRN applied once per year produced equal or better TSS yield than AN applied twice per year. Boman (1993) compared single annual applications of polymer-coated CRN to mature 'Marsh' grapefruit trees with a split annual application of soluble $\mathrm{N}$ and found only minor differences in fruit yield and juice quality between treatments during a 4-year period.

At the same time the above experiments were undertaken, new large-scale citrus plantings in southern Florida and major replant programs in other parts of the state led to considerable experimentation with $\mathrm{CRN}$ as part of young tree nutritional programs (Alva and
Tucker, 1993; Davies et al., 1996; Ferguson et al., 1988; Jackson and Davies, 1984; Marler et al, 1987; Obreza, 1990, 1993; Obreza and Rouse, 1992, 1993; Zekri and Koo, 1991, 1992). Since fertilizer recommendations called for four to six annual $\mathrm{N}$ applications during the nonbearing years (Koo et al., 1984), the impetus to experiment with CRN centered on decreasing the number of trips through the orchard to lower application cost, as well as the aforementioned environmental advantage. These experiments were 1 to 3 year studies of the effects of a wide range of CRN materials on young tree growth and in some cases soil $\mathrm{N}$ concentration. General conclusions by the authors were 1) trunk diameter or canopy volume increase was as good or better with CRN applied less frequently or at lower rates compared with soluble $\mathrm{N}$ applied at higher frequency or rates; and 2) less $\mathrm{N}$ leaching was a likely result of using $\mathrm{CRN}$ in place of soluble N.

There are no published Florida studies that have combined young and mature tree fertilization strategies to illustrate the long-term effect of CRN-containing fertilizer applied to citrus trees from planting into the bearing years. This experiment investigated the long-term use of MU and IBDU to supply a portion of the citrus $\mathrm{N}$ requirement on a sandy soil low in natural fertility. These two materials represent older yet still viable CRN technologies. MU is a ureaformaldehyde reaction product that evolved during the 1960s and 70s (Sartain and Kruse, 2001). Its conversion to plant-available $\mathrm{N}$ is a multi-step process involving dissolution followed by microbial decomposition to urea. Since $\mathrm{N}$ release is a biological process, any environmental factor that affects microbial activity (e.g., moisture and temperature) will also affect the release rate of the material. Research on turfgrass during the summer in Florida showed that most of the $\mathrm{N}$ from MU released in about 90 d (J.B. Sartain, personal communication). IBDU, which evolved in the 1970 s, releases its $\mathrm{N}$ in a shorter period (about $60 \mathrm{~d}$ in the summer) because release does not rely on microbial action. In the presence of water, IBDU dissolves slowly and then hydrolyzes, producing urea. The rate of this process is accelerated at low $\mathrm{pH}$ and high temperature. The dissolution rate is affected by particle size and the amount of water available.

The objective of this study was to compare long-term citrus growth, fruit, and TSS production between $\mathrm{N}$ fertilizer programs containing CRN (IBDU or MU) and a Univ. of Florida-recommended soluble $\mathrm{N}$ fertilizer program. The results will help determine the magnitude of horticultural utility provided by CRN if incorporated into a citrus nutrient BMP program.

\section{Materials and Methods}

We conducted this experiment in a commercial southwest Florida citrus orchard planted on Pople fine sand (loamy, siliceous, hyperthermic Arenic Ochraqualf) and Holopaw sand (loamy, siliceous, hyperthermic Grossarenic Ochraqualf). These soils were poorly-drained 
Table 1. Fertilizer treatments applied in each year of the experiment (four $\mathrm{N}$ rates $\times$ three $\mathrm{N}$ sources $=12$ treatments). $(\mathrm{AN}=$ ammonium nitrate; IBDU $=$ isobutylidene diurea; $\mathrm{MU}=$ methylene urea).

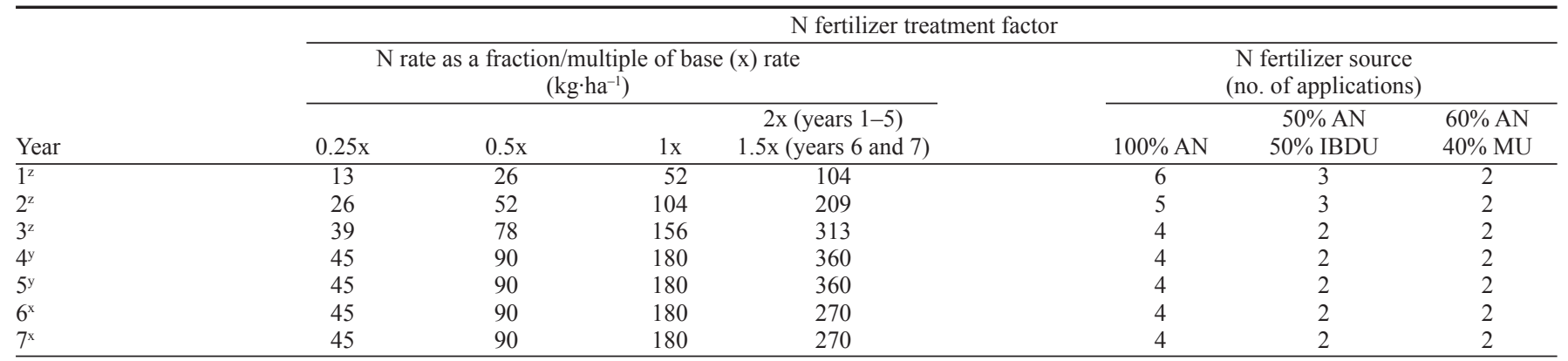

${ }^{2} \mathrm{P}$ and $\mathrm{K}$ fertilizers were applied at $23 \%$ and $83 \%$ and of the $\mathrm{N}$ rate applied to each treatment, respectively.

${ }^{\mathrm{y}} \mathrm{K}$ fertilizer was applied at $280 \mathrm{~kg} \mathrm{~K} / \mathrm{ha}$ to all treatments in four equal doses that matched the $100 \% \mathrm{AN}$ schedule; no P fertilizer was applied.

${ }^{x} \mathrm{~K}$ fertilizer was applied at $186 \mathrm{~kg} \mathrm{~K} / \mathrm{ha}$ to all treatments in four equal doses that matched the $100 \% \mathrm{AN}$ schedule; no P fertilizer was applied.

in their native state, so orchard development included construction of parallel 15.3-m-wide beds with 1-m-deep furrows in between to improve surface drainage. Following bed construction, the organic matter content in the top $30 \mathrm{~cm}$ of soil was between $1 \%$ and $2 \%$.

In Mar. 1989, each bed was planted with two north-south rows of 'Hamlin' orange trees on Carrizo citrange $(C$. sinensis $\times$ Poncirus trifoliata L. Raf.) rootstock at a spacing of 2.7 $\mathrm{m}$ (in-row) $\times 7.6 \mathrm{~m}$ (between-row), giving a density of 487 trees/ha. We used four adjacent rows in the middle of a large orchard block. The area was divided into eight blocks (replications) along a low (4.3) to high (8.1) soil $\mathrm{pH}$ gradient from south to north. Plots within each block consisted of four adjacent trees within a row. One replication of each fertilizer treatment was randomly assigned to a plot within each block. The orchard was subirrigated by an artificial water table maintained between 0.60 and $0.75 \mathrm{~m}$ below the soil surface. Standard commercial orchard care other than fertilization was supplied by the grower-cooperator, including row middle mowing, herbiciding under the tree canopy, irrigation, and insect and disease management.

The study evaluated three $\mathrm{N}$ fertilizer sources and four $\mathrm{N}$ rates in a randomized complete block full factorial experimental design (Table 1). In the first 3 years, we applied three complete fertilizers $(8 \mathrm{~N}-1.8 \mathrm{P}-6.6 \mathrm{~K})$ that differed in $\mathrm{N}$ composition. One contained entirely soluble $\mathrm{N}$ (AN), while the other two were blends of soluble $\mathrm{N}$ and $\mathrm{CRN}$. The first of these was a 50/50 mixture of AN/IBDU, and the second was a 60/40 mixture of AN/MU. Each fertilizer was applied at a base rate and three additional rates as fraction or multiple of the base (Table 1). The base $\mathrm{N}$ rate was within the range recommended for young citrus trees (Koo et al., 1984). Application frequency of soluble $\mathrm{N}$ fertilizer also followed established guidelines for young trees (Koo et al., 1984), while the soluble N-CRN blends were applied about half to one-third as frequently based on advice from the manufacturers (Table 1). We fertilized trees by hand throughout the duration of the experiment. Details regarding fertilizer composition with respect to elements other than $\mathrm{N}$ and the split application timing in the first 3 years have been published elsewhere (Obreza and Rouse 1992, 1993).
At the end of the 3rd year, we measured an average orange yield of $24 \mathrm{~kg} /$ tree from trees receiving the highest two $\mathrm{N}$ rates, so we considered the orchard bearing as it entered year 4. Beginning that year, fertilizers were changed from the preblended mixtures described above to straight $\mathrm{N}$ and $\mathrm{K}$ materials so the $\mathrm{N}$ effect could be isolated. $\mathrm{N}$ fertilizer continued to be applied as either AN, AN/IBDU (50/50), or AN/MU (60/40) as in years 1 through 3, but K in year 4 and 5 was applied as $\mathrm{KCl}$ separately across all plots at a uniform rate of $280 \mathrm{~kg}$ $\mathrm{K} / \mathrm{ha}$. Following year 5, leaf tissue analysis indicated this $\mathrm{K}$ rate was higher than needed, so we lowered it to $186 \mathrm{~kg} \mathrm{~K} / \mathrm{ha}$ in year 6 and 7 (Table 1). Soil tests after year 3 indicated sufficient residual soil $\mathrm{P}$ build-up from previous fertilization, so no further $\mathrm{P}$ applications were made.

The base $\mathrm{N}$ fertilizer rate in years 4 through 7 was within the recommended range (Koo et al., 1984) and was at the lower end of the scale typically used by growers to produce oranges in southwestern Florida (180 to $225 \mathrm{~kg} \mathrm{~N} / \mathrm{ha}$ ). Additional rates applied were fractions or multiples similar to those used in the earlier years. In year 6 and 7 we decreased the high rate from 2 to 1.5 times the base rate in order to avoid excessive $\mathrm{N}$ fertilization (Table 1). The AN treatment was applied in four equal annual applications (March, May, August, and November), while the AN/IBDU and AN/MU treatments were applied in two equal applications (March and August).

Leaftissue (4-to 6-month-old spring growth from nonfruiting twigs) sampled from each plot every August was analyzed for total $\mathrm{N}$ and other nutrients. We measured fruit yield in December each year. Fruits from the middle two trees in each plot were harvested and weighed. A random subsample of 40 to 45 oranges from each plot was taken for juice quality evaluation. Orange juice was extracted using a commercial extractor(FMC Corp.,Agricultural Machinery Div., Jonesboro, Ark.). Juice quality parameters included percentage juice per fruit, TSS measured with a Brix hydrometer (Wardowski et al., 1979), acid concentration measured by alkali titration (Wardowski et al., 1979), and TSS:acid ratio. TSS yield in $\mathrm{g} \cdot \mathrm{kg}^{-1}$ fruit and $\mathrm{kg} /$ tree were calculated from yield, percentage juice, and TSS in the juice.

Analysis of variance and linear and nonlinear regression were used to determine main effects and interactions of $\mathrm{N}$ source and rate on yield and juice quality variables. Only seven replications were used in the data analysis because after the first 3 years of the experiment, we observed that the acidic soil $\mathrm{pH}$ in the southernmost block (replication) had

Table 2. Main effects of $\mathrm{N}$ fertilizer source on fruit yield, juice quality, total soluble solids (TSS) yield, and leaf tissue $\mathrm{N}$ concentration of 'Hamlin' orange trees.

\begin{tabular}{llcccc}
\hline N source & Year 4 & Year 5 & Year 6 & Year 7 & Years 4-7 \\
\hline Fruit yield (kg/tree) & & & & & \\
$\quad$ AN & $91.1 \mathrm{a}^{\mathrm{z}}$ & 95.8 & $108.4 \mathrm{a}$ & $127.8^{\mathrm{y}}$ & $424.1^{\mathrm{x}}$ \\
AN/IBDU & $93.1 \mathrm{a}$ & 94.4 & $97.2 \mathrm{a}$ & $130.6^{\mathrm{y}}$ & $419.2^{\mathrm{x}}$ \\
AN/MU & $82.4 \mathrm{~b}$ & 89.2 & $83.8 \mathrm{~b}$ & $138.3^{\mathrm{y}}$ & $393.6^{\mathrm{x}}$ \\
Juice quality (g TSS/kg fruit) & & & & & \\
AN & 50.6 & 60.4 & 53.8 & $53.4 \mathrm{~b}$ & $54.5^{\mathrm{w}}$ \\
AN/IBDU & 52.4 & 60.9 & 52.5 & $55.7 \mathrm{ab}$ & $55.4^{\mathrm{w}}$ \\
AN/MU & 52.4 & 62.0 & 53.8 & $56.9 \mathrm{a}$ & $56.3^{\mathrm{w}}$ \\
TSS yield (kg/tree) & & & & & \\
AN & $4.62 \mathrm{ab}$ & 5.78 & $5.88 \mathrm{a}$ & $6.88^{\mathrm{y}}$ & $23.14^{\mathrm{x}}$ \\
AN/IBDU & $4.86 \mathrm{a}$ & 5.79 & $5.04 \mathrm{~b}$ & $7.41^{\mathrm{y}}$ & $23.28^{\mathrm{x}}$ \\
AN/MU & $4.31 \mathrm{~b}$ & 5.51 & $4.59 \mathrm{~b}$ & $7.86^{\mathrm{y}}$ & $22.26^{\mathrm{x}}$ \\
Leaf N (\%) & & --- & & & \\
AN & --- & --- & 2.4 & 2.4 & -- \\
AN/IBDU & --- & --- & 2.4 & 2.5 & -- \\
AN/MU & & & 2.3 & 2.4 & -- \\
\hline
\end{tabular}

${ }^{2}$ In columns with letters present, means followed by the same letter are not significantly different at $P \leq$ 0.05 according to Duncan's multiple range test.

${ }^{y}$ See Table 3 for interaction between $\mathrm{N}$ rate and source.

${ }^{\mathrm{x}}$ Sum of years 4 through 7 .

"Mean of years 4 through 7 . 
Table 3. Effects of $\mathrm{N}$ fertilizer source by $\mathrm{N}$ rate on fruit yield and total soluble solids (TSS) yield in year 7 (significant interaction between $\mathrm{N}$ rate and source).

\begin{tabular}{lcccc}
\hline & \multicolumn{4}{c}{ Fraction of base N rate } \\
\cline { 2 - 5 } N source & $0.25 \mathrm{x}$ & $0.5 \mathrm{x}$ & $1 \mathrm{x}$ & $1.5 \mathrm{x}$ \\
\hline Fruit yield (kg/tree) & 99.4 & 115.2 & $134.4 \mathrm{~b}$ & 162.0 \\
AN & 100.9 & 110.3 & $149.4 \mathrm{ab}$ & 161.6 \\
AN/IBDU & 140.2 & 108.1 & $173.8 \mathrm{a}$ & 131.1 \\
AN/MU & & & & \\
TSS yield (kg/tree) & $5.11 \mathrm{~b}$ & 6.17 & $7.42 \mathrm{~b}$ & 8.80 \\
AN & $4.97 \mathrm{~b}$ & 6.39 & $9.23 \mathrm{ab}$ & 9.06 \\
AN/IBDU & $7.80 \mathrm{a}$ & 6.04 & $10.37 \mathrm{a}$ & 7.22 \\
AN/MU & & & & \\
\hline
\end{tabular}

${ }^{2}$ In columns with letters present, means followed by the same letter are not significantly different at $P \leq$ 0.05 according to Duncan's multiple range test.

suppressed tree growth and was substantially impacting yield. Mean yields in the affected block were less than half of the mean yields in the seven blocks to the north.

Since TSS yield integrates both yield and juice quality responses, we used it as the main result to evaluate treatments. A linear-plateau segmented model (SAS Institute, 1982) was fitted to the data relating TSS yield to $\mathrm{N}$ rate: TSS yield $=\mathrm{A}+\mathrm{B}(\mathrm{x})$ (when $\mathrm{x}$ is below the critical rate); TSS yield $=\mathrm{A}+\mathrm{B}(\mathrm{CR})$ ( when $\mathrm{x}$ is above the critical rate), where $\mathrm{x}=$ annual $\mathrm{N}$ rate $\left(\mathrm{kg} \cdot \mathrm{ha}^{-1}\right)$ and $\mathrm{CR}=$ critical fertilizer rate (the point at which maximum yield is reached). We used Duncan's multiple range test to evaluate the effect of fertilizer source.

\section{Results and Discussion}

Tree response observed during the first 3 years of the experiment was reported by Obreza and Rouse (1993), and additional data describing early-year responses can be found in Obreza (1993). This paper describes fruit yield, juice quality, and TSS yield responses measured in years 4 through 7 that resulted from the long-term effects of $\mathrm{CRN}$-containing fertilizers applied at lower than recommended frequency. Statistical analysis of the factorial $N$ source and rate combinations revealed almost no interaction between the two for the responses measured. The only significant interaction was measured in year 7 for fruit and TSS yields, so except for these two instances, tree responses are discussed in terms of main effects.

In years 4 through 7 , mean annual orange yields across all plots were 88.8, 93.1, 96.5, and $132.4 \mathrm{~kg} /$ tree, respectively. By year 7 , trees that received either of the two highest $\mathrm{N}$ rates produced an average fruit load of 153 $\mathrm{kg}$, which translated to a yield of $74.5 \mathrm{Mg} \cdot \mathrm{ha}^{-1}$ considering the tree population (equivalent to a 738 box/acre yield, where 1 box $=90 \mathrm{lb}$ of fruit). This orchard was considered very productive according to Florida's current citrus nutrition guide (Tucker et al., 1995), so we considered the experiment to be a rigorous test of the ability of MU and IBDU to supply $\mathrm{N}$ in a high-demand situation.

Nitrogen source affected fruit yield across all rates in years 4 and 6 (Table 2), and at the $180 \mathrm{~kg} \cdot \mathrm{ha}^{-1}$ rate in year 7 (Table 3). In year 4, AN and AN/IBDU produced about $12 \%$ more fruit than AN/MU. In year 6, AN and AN/IBDU produced $29 \%$ and $16 \%$ more fruit, respectively, than AN/MU. However, in year
7, AN/MU produced $29 \%$ more fruit than AN at the $180 \mathrm{~kg} \cdot \mathrm{ha}^{-1}$ rate. Juice quality was not affected by $\mathrm{N}$ source except in year 7 , when AN/MU produced about $6 \%$ more TSS per $\mathrm{kg}$ fruit than AN (Table 2). TSS yield, which varied primarily due to differences in fruit yield, was affected by $\mathrm{N}$ source across all $\mathrm{N}$ rates in years 4 and 6 (Table 2) and at the 45 and $180 \mathrm{~kg} \cdot \mathrm{ha}^{-1} \mathrm{~N}$ rates in year 7 (Table 3 ). In year 4, AN/IBDU produced about $13 \%$ more TSS than AN/MU, with the AN treatment in between. In year 6 , AN produced $17 \%$ more TSS than AN/IBDU and 28\% more TSS than AN/MU. In year 7, TSS yield was $40 \%$ higher with AN/MU compared with $\mathrm{AN}$ at the 180 $\mathrm{kg} \cdot \mathrm{ha}^{-1} \mathrm{~N}$ rate, and it was $55 \%$ higher with AN/MU compared with either AN or AN/IBDU at the $45 \mathrm{~kg} \cdot \mathrm{ha}^{-1} \mathrm{~N}$ rate.

Summing fruit and TSS yields for years 4 through 7 provided a more comprehensive view of $\mathrm{N}$ source effects (Table 2). Smoothing of year-to-year variation eliminated statistical differences due to $\mathrm{N}$ source, so we considered all of them to be equally effective for fruit production in the long term. In the same manner, juice quality averaged over the 4-year period was not affected by $\mathrm{N}$ source (Table 2). Leaf tissue $\mathrm{N}$ was not affected by $N$ source in years 6 and 7 (Table 2).

The response of TSS yield to $\mathrm{N}$ fertilizer rate was described by a linear-plateau function in years 4 and 5 for all sources and in year 7 for AN/IBDU. The response was linear for all sources in year 6 and for AN in year 7 (Fig. 1). A fluctuating $\mathrm{N}$ rate response for $\mathrm{AN} / \mathrm{MU}$ in year 7 could not be fitted to any conventional mathematical model. The higher than expected yield at the lowest $\mathrm{N}$ rate and lower than expected yield at the highest $\mathrm{N}$ rate for this treatment

Fig. 1. TSS yield response to $\mathrm{N}$ fertilizer rate in years 4 through 7 of the experiment. (Significant interaction between $\mathrm{N}$ source and rate in year 7). could not be explained in terms of experimental factors, so we attributed it to random error effects. Critical $\mathrm{N}$ rates as estimated by the linear-plateau model varied between 178 and $214 \mathrm{~kg} \cdot \mathrm{ha}^{-1}$, with corresponding plateau TSS yields of 5.7 to $9.2 \mathrm{~kg} /$ tree depending on year. The linear response of TSS to all $\mathrm{N}$ sources in year 6 may have been the result of climatic conditions that were conducive for higher than normal fruit production, but available climatic data (solar radiation, potential evapotranspiration) do not support this postulation. The improved efficiency of fertilizers containing CRN was evident in year 7 , when the base rate of AN/MU and AN/IBDU produced greater TSS yield than 1.5 times the base rate of AN (Fig. 1). Year 7 was a substantially wetter year compared with years 4 to 6 . Year 7 rainfall from March through October totaled $173 \mathrm{~cm}$, while it ranged between 102 and $105 \mathrm{~cm}$ for the same time period in years 4,5 , and 6 .

Summing or averaging the 4-year response data simplified the $\mathrm{N}$ rate response analysis as it did with the $\mathrm{N}$ source data. Relationships of fruit yield, juice quality, and TSS yield to average annual $\mathrm{N}$ rate were described well by the linear plateau model (Fig. 2). The critical $\mathrm{N}$ rate for fruit and TSS yield was right about $200 \mathrm{~kg} \cdot \mathrm{ha}^{-1}$. Whereas N source did not affect juice quality, increasing $\mathrm{N}$ rate improved juice
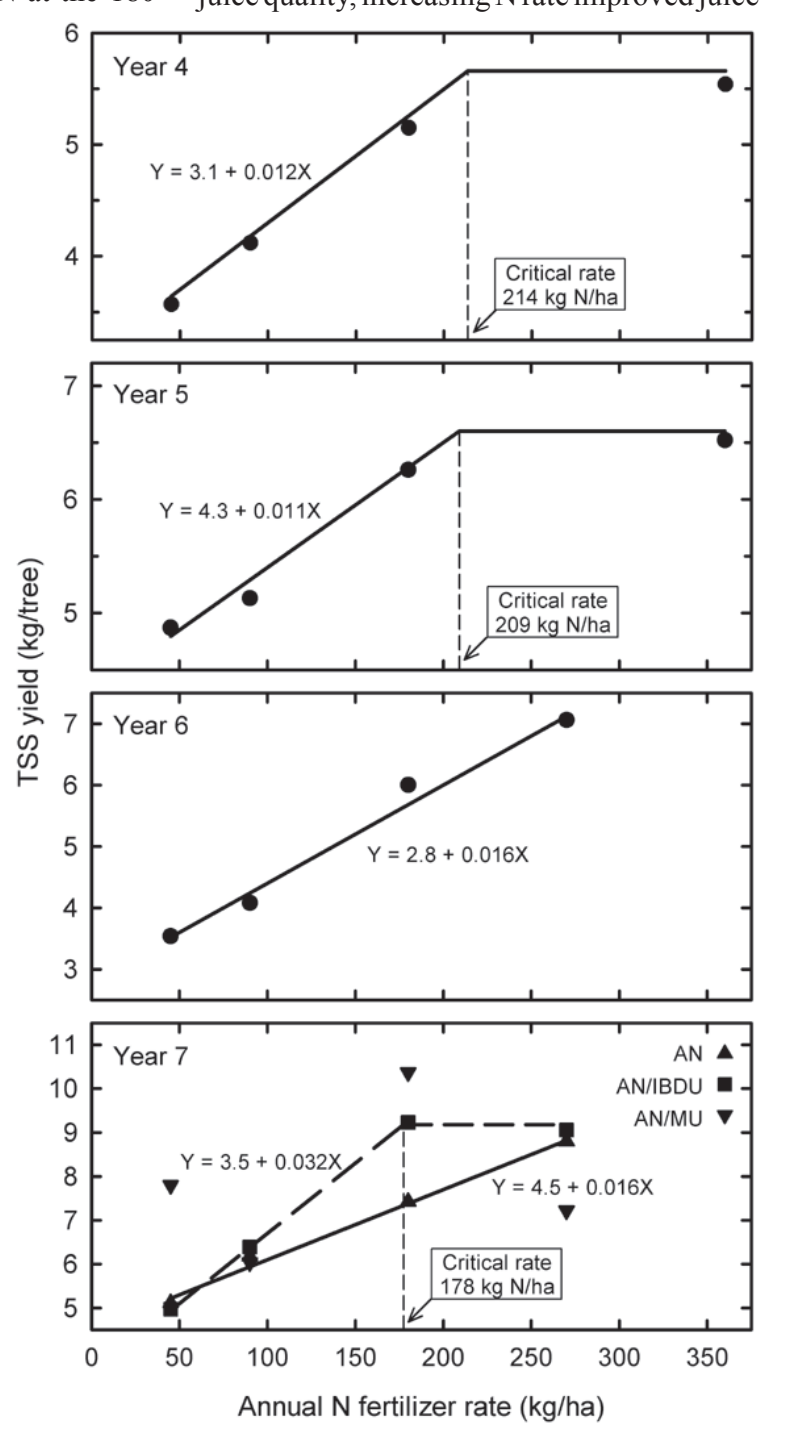

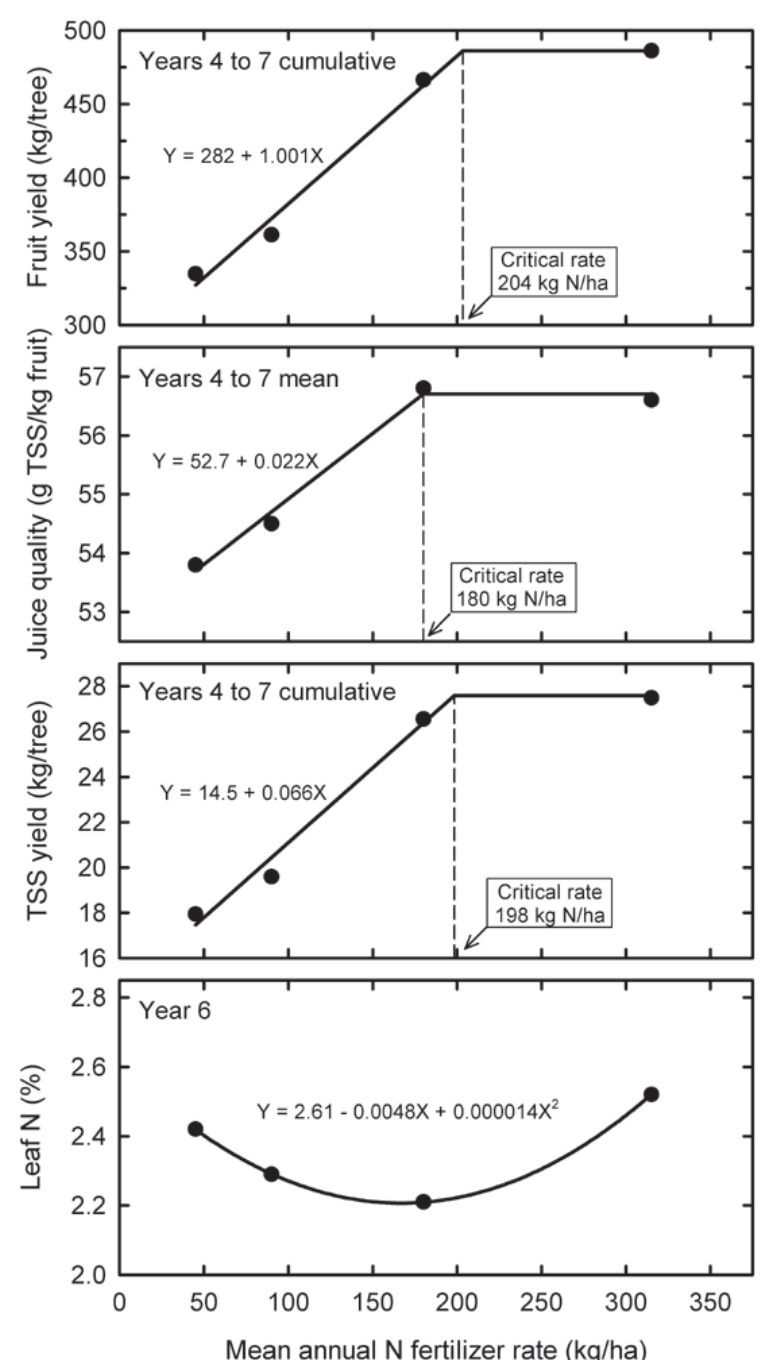

Fig. 2. Responses of years 4 through 7 cumulative fruit yield and TSS yield and mean juice quality, and year 6 leaf tissue $\mathrm{N}$ to mean annual $\mathrm{N}$ fertilizer rate.

quality until about $180 \mathrm{~kg} \cdot \mathrm{ha}^{-1}$ was reached, after which no further increase was observed. It is important to realize that relationships of both fruit yield and juice quality to $\mathrm{N}$ rate need to be considered when determining the critical rate required for TSS production. $\mathrm{N}$ rate significantly affected leaf $\mathrm{N}$ concentration in year 6 only, and the relationship was quadratic (Fig. 2). The fact that leaf $\mathrm{N}$ across all treatments was slightly below the optimum range of $2.4 \%$ to $2.6 \%$ (Tucker et al., 1995) did not appear to be a significant concern.

In this study, citrus trees in a commercial orchard were subjected to one conventional (soluble $\mathrm{N}$ ) and two potential nutrient BMP (soluble-CRN blends) fertilizer programs for 7 years after planting. Horticultural responses expressed as tree growth, fruit yield, juice quality, and TSS yield were similar between programs, especially when year-to-year variation was taken into account. Controlled-release blends were as effective as $100 \%$ soluble fertilizer in providing $\mathrm{N}$ to a high-producing orange orchard, despite being applied about half as frequently. In 7 years, AN, AN/IBDU, and AN/ MU fertilizers were applied 31, 16 , and 14 times, respectively. As fuel prices increase, producers will take more notice of opportunities to decrease fertilizer applicator trips through the orchard.

The observed long-term $\mathrm{N}$ rate response suggests that maximum TSS yield can be achieved by applying an average of $200 \mathrm{~kg} \mathrm{~N} / \mathrm{ha} /$ year in a 3- to 4-year period, which is in line with the current Florida recommendation (Tucker et al., 1995). In some years it may be possible to decrease the $\mathrm{N}$ rate without affecting yield when using CRN in the program, but our study did not show this to be consistently the case. We feel the CRN materials tested could be successfully used in the long term by Florida citrus producers as part of a nutritional BMP program to maintain high yields while potentially decreasing $\mathrm{N}$ loss to the environment.

\section{Literature Cited}

Alva, A.K. and D.P.H. Tucker. 1993. Evaluation of a resin-coated nitrogen fertilizer for young citrus trees on a deep sand. Proc. Fla. State Hort. Soc. 106:4-8.

Boman, B.J. 1993. A comparison of controlled-release to conventional fertilizer on mature 'Marsh' grapefruit. Proc. Fla. State Hort. Soc. 106:1-4.

Davies, F.S., M. Tignor, and L.A. Mathers. 1996. Irrigation and fertilization of young interset
'Hamlin' orange trees in Florida. Proc. Fla. State Hort. Soc. 109:77-80.

Ferguson, J.J., F.S. Davies, C.H. Matthews, and R.M. Davis. 1988. Controlled-release fertilizers and growth of young 'Hamlin' orange trees. Proc. Fla. State Hort. Soc. 101:17-20.

Jackson, L.K. and F.S. Davies. 1984. Mulches and slow-release fertilizers in a citrus young tree care program. Proc. Fla. State Hort. Soc. 97:37-39.

Koo, R.C.J., C.A. Anderson, I. Stewart, D.P.H Tucker, D.V. Calvert, and H.K. Wutscher. 1984. Recommended fertilizers and nutritional sprays for citrus. Fla. Agr. Expt. Sta. Bul. 536D.

Koo, R.C.J. 1986. Controlled-release sources of nitrogen for bearing citrus. Proc. Fla. State Hort. Soc. 99:46-48.

Leonard, C.D., I. Stewart, and I.W. Wander. 1961. A comparison of ten nitrogen sources for Valencia oranges. Proc. Fla. State Hort. Soc. 74:79-86.

Marler, T.E., J.J. Ferguson, and F.S. Davies. 1987. Growth of young 'Hamlin' orange trees using standard and controlled-release fertilizers. Proc. Fla. State Hort. Soc. 100:61-64.

Obreza, T.A. 1990. Young 'Hamlin' orange tree fertilizer response in southwest Florida. Proc. Fla. State Hort. Soc. 103:12-16.

Obreza, T.A. and R.E. Rouse. 1992. Controlledrelease fertilizer use on young 'Hamlin' orange trees. Soil Crop Sci. Soc. Fla. Proc. 51:64-68.

Obreza, T.A. and R.E. Rouse. 1993. Fertilizer effects on early growth and yield of 'Hamlin' orange trees. HortScience 28(2):111-114.

Obreza, T.A. 1993. Program fertilization for establishment of orange trees. J. Prod. Agr. 6:546-552.

Paramasivam, S., A.K. Alva, A. Fares, and K.S. Sajwan. 2001. Estimation of nitrate leaching in an Entisol under optimum citrus production. Soil Sci. Soc. Am. J. 65:914-921.

Sartain, J.B. and J.K. Kruse. 2001. Selected fertilizers used in turfgrass fertilization. Fla. Coop. Ext. Serv. Circ. 1262.

SAS Institute. 1982. SAS user's guide: Statistics. SAS Inst., Cary, N.C.

Smith, P.F., G.K. Scudder, Jr., and G. Hrnciar. 1968.A comparison of nitrogen sources, rates, and placement on the performance of Pineapple orange trees. Proc. Fla. State Hort. Soc. 81:25-29.

Tucker, D.P.H., A.K. Alva, L.K. Jackson, and T.A. Wheaton. 1995. Nutrition of Florida citrus trees. Fla. Agr. Expt. Sta. Bul. SP-169.

Wang, F. and A.K. Alva. 1996. Leaching of nitrogen from slow-release urea sources in sandy soils. Soil Sci. Soc. Amer. J. 60:1454-1458.

Wardowski, W., J. Soule, W. Grierson, and G. Westbrook. 1979. Florida citrus quality tests. Fla. Coop. Ext. Serv. Bul. 188.

Zekri, M. and R.C.J. Koo. 1991. Evaluation of controlled-release fertilizers for young citrus trees. J. Amer. Soc. Hort Sci. 116:987-990.

Zekri, M. and R.C.J. Koo. 1992. Use of controlled release fertilizers for young citrus trees. Scientia Hort. 49:233-241. 